\title{
Pregnancy and contraception in heart disease and pulmonary arterial hypertension
}

\author{
Sara Thorne, Catherine Nelson-Piercy, Anne MacGregor, Simon Gibbs, John Crowhurst, Nick Panay, \\ Eric Rosenthal, Fiona Walker, David Williams, Michael de Swiet, John Guillebaud
}

\section{Introduction}

Heart disease is the leading cause of maternal mortality in the UK. ${ }^{1}$ There is therefore a need to disseminate amongst the medical profession accurate information about contraception and pre-pregnancy counselling for women with heart disease.

The risk of pregnancy depends on the specific disease and the individual patient. For example, the risk of maternal death is up to $50 \%$ for those with pulmonary arterial hypertension, but there is no anticipated extra risk for those with mild pulmonary stenosis compared to women without heart disease. Similarly, although certain contraceptive methods are associated with unacceptable increases in risk for specific cardiac conditions, it is not the case that "most structural heart disease" is an absolute contraindication for use of the combined oral contraceptive $(\mathrm{COC}){ }^{2}$

There is a paucity of published information and very little evidence base about contraception in women with heart disease. Thus health care professionals who offer advice to such women may err on the side of caution, being reluctant to advise some methods that may in fact be appropriate. A lack of knowledge by non-specialists of the

J Fam Plann Reprod Health Care 2006; 32(2): 75-81

(Accepted 16 January 2006)

University Hospital Birmingham, Birmingham, UK

Sara Thorne, MD, FRCP, Consultant Cardiologist

St Thomas' Hospital, London, UK

Catherine Nelson-Piercy, Qualifications, Consultant Obstetric Physician

Eric Rosenthal, MD, FRCP, Consultant Paediatric Cardiologist

Barts Sexual Health Centre, St Bartholomew's Hospital,

London, UK

Anne MacGregor, MFFP, Senior Clinical Medical Officer

Department of Cardiovascular Medicine, Imperial College School of Medicine, Hammersmith Hospital, London, UK Simon Gibbs, MD, FRCP, Senior Lecturer

Hammersmith Hospital, London, UK

John Crowhurst, Dip(Obst) RCOG, FRCA, Consultant Anaesthetist

Nick Panay, MRCOG, MFFP, Consultant Obstetrician and

Gynaecologist

Middlesex Hospital, London, UK

Fiona Walker, BM, MRCP, Consultant Cardiologist

Elizabeth Garrett Anderson Obstetric Hospital, London, UK David Williams, PhD, MRCP, Consultant Obstetric Physician

Institute of Reproductive and Developmental Biology, Imperial College, Queen Charlotte's and Chelsea Hospital, London, UK

Michael de Swiet, MD, FRCP, Emeritus Professor of Obstetric

Medicine and Consultant Obstetric Physician

University College London and Margaret Pyke Memorial Trust, London, UK

John Guillebaud, FRCOG, Hon FFFP, Emeritus Professor of Family

Planning and Reproductive Health

Correspondence to: Dr Sara Thorne, University Hospital

Birmingham, Birmingham B15 2TH, UK.

Tel: +44 (0) 121627 2959. Fax: +44 (0) 1216272862.

E-mail: sara.thorne@uhb.nhs.uk range of effective contraceptive measures available may result in the highest-risk women being denied effective contraception and having unplanned pregnancies. ${ }^{3}$ Conversely, those with less severe lesions receive inappropriate advice regarding (primarily) oral contraception, again leading to unintended conceptions. ${ }^{3}$ In extreme examples, women may even be advised to undergo unnecessary termination of pregnancy for a cardiac condition that has little or no increased risk in pregnancy.

The lack of specialist cardiac services for the growing number of adolescents and adults with congenital heart disease (CHD) may compound the problem. Many cardiologists have little knowledge of the interactions between complex heart disease, pregnancy and its prevention. Family planning needs and preconceptual advice for adults with CHD are presently generally poorly provided for. ${ }^{3}$ All these women need advice arising from a combined approach between family planning clinicians and cardiologists with relevant special skills and interests. This counselling should always respect the woman's autonomy.

For the above reasons, a group of obstetricians, gynaecologists, experts in contraception, obstetric physicians, cardiologists and specialists in adult CHD was convened. This working group met on several occasions and corresponded over 2 years to produce a consensus document outlining recommendations on pregnancy and contraception for women with heart disease. Since women with heart disease are not a homogeneous group, the aim of this review and the resulting recommendations is to provide risk stratification for both pregnancy and individual contraceptive methods in women with cardiac disease.

Table 1 World Health Organization (WHO) risk classifications by medical condition for contraceptive method and pregnancy

\begin{tabular}{|c|c|c|}
\hline WHO Class & $\begin{array}{l}\text { Risk for contraceptive } \\
\text { method by medical } \\
\text { condition }\end{array}$ & $\begin{array}{l}\text { Risk for pregnancy by medical } \\
\text { condition }\end{array}$ \\
\hline 1 & $\begin{array}{l}\text { Condition with no } \\
\text { restriction for the use of } \\
\text { the contraceptive method } \\
\text { Always usable }\end{array}$ & $\begin{array}{l}\text { No detectable increased risk of } \\
\text { maternal mortality or } \\
\text { morbidity }\end{array}$ \\
\hline 2 & $\begin{array}{l}\text { Condition where the } \\
\text { advantages of the method } \\
\text { generally outweigh the } \\
\text { risks } \\
\text { Broadly usable }\end{array}$ & $\begin{array}{l}\text { Small increased risk of } \\
\text { maternal mortality or } \\
\text { morbidity }\end{array}$ \\
\hline 3 & $\begin{array}{l}\text { Condition where the risks } \\
\text { of the method usually } \\
\text { outweigh the advantages: } \\
\text { alternatives are usually } \\
\text { preferable. Exceptions if: } \\
\text { (i) Patient accepts risks } \\
\text { and rejects alternatives } \\
\text { (ii) The risk of pregnancy } \\
\text { is very high and the only } \\
\text { acceptable alternative } \\
\text { methods are less effective } \\
\text { Caution in use }\end{array}$ & $\begin{array}{l}\text { Significantly increased risk of } \\
\text { maternal mortality or severe } \\
\text { morbidity. Expert counselling } \\
\text { required. If pregnancy is } \\
\text { decided upon, intensive } \\
\text { specialist cardiac and obstetric } \\
\text { monitoring needed throughout } \\
\text { pregnancy, childbirth and the } \\
\text { puerperium }\end{array}$ \\
\hline 4 & $\begin{array}{l}\text { Condition where the } \\
\text { method represents an } \\
\text { unacceptable health risk } \\
\text { Do not use }\end{array}$ & $\begin{array}{l}\text { Extremely high risk of } \\
\text { maternal mortality or severe } \\
\text { morbidity: pregnancy } \\
\text { contraindicated. If pregnancy } \\
\text { occurs termination should be } \\
\text { discussed. If pregnancy } \\
\text { continues, care as for Class } 3\end{array}$ \\
\hline
\end{tabular}


The working group agreed that the World Health Organization (WHO) classification of contraindications for contraceptive use would be a useful tool for addressing suitability of specific contraceptive methods 4,5 and, in addition, could be modified to stratify risk for pregnancy in heart disease (Table 1).

Discussion of the risks of pregnancy and reasons for advising a particular contraceptive method must be documented in the patient's notes. This is particularly relevant to WHO Classes 3 and 4.

\section{Risks of pregnancy}

All women with heart disease should be referred to, or discussed with, a cardiologist with relevant skills prior to conceiving. For those with $\mathrm{CHD}$, discussions regarding pregnancy and contraception should be initiated in the paediatric cardiology clinics as part of the broader process of transition to adulthood.

All women with CHD should have access to preconception counselling from a specialist in adult CHD.

This section classifies maternal risk according to cardiac condition. Risk is additive, so for each individual, the risk of a pregnancy may move up a class if there are further risk factors such as hypertension, diabetes and major musculoskeletal abnormalities.

The risk of an adverse cardiac event during the pregnancy of a woman with heart disease may also be estimated from the following risk factors:

- cyanosis $\left(\mathrm{SaO}_{2}<90 \%\right)$

- New York Heart Association (NYHA) symptoms $>$ Functional Class II

- systemic ventricular ejection fraction $<40 \%$

- prior cardiovascular event (arrhythmia, pulmonary oedema, stroke or transient ischaemic attack).

If one risk factor is present, the additional risk of an adverse cardiac event in the current pregnancy is $27 \%$; if two or more, the risk is $75 \% .6$

\section{Class 4 Conditions (Table 2)}

- Pregnancy presents an extremely high risk of maternal mortality or severe morbidity and is contraindicated. If pregnancy occurs, termination should be discussed. If pregnancy continues, care as for Class 3.

\section{Pulmonary arterial hypertension}

Pulmonary arterial hypertension 7,8 from any cause is associated with a maternal mortality of up to $50 \% .{ }^{9}$ It is believed that it is the increase in pulmonary vascular resistance with subsequent inability to increase pulmonary blood flow that makes pregnancy so dangerous and places it in the Class 4 category.

Pulmonary arterial hypertension is defined as a nonpregnant elevation of mean (not systolic) pulmonary artery pressure $\geq 25 \mathrm{mmHg}$ at rest or $30 \mathrm{mmHg}$ on exercise in the absence of a left-to-right shunt. Mild pulmonary arterial hypertension can also be defined as a pulmonary artery systolic pressure of $\sim 36-50 \mathrm{mmHg}$.

Pulmonary artery systolic pressure is usually estimated by using Doppler ultrasound to measure the regurgitant jet velocity across the tricuspid valve. A peak tricuspid

Table 2 Conditions in which pregnancy is Class 4

Pulmonary arterial hypertension of any cause

Severe systemic ventricular dysfunction

NYHA III-IV or ventricular ejection fraction $<30 \%$

Previous peripartum cardiomyopathy with any residual impairment of left ventricular function

Severe left heart obstruction

Marfan syndrome with aorta dilated $>40 \mathrm{~mm}$ regurgitant velocity of $2.8-3.4 \mathrm{~m} / \mathrm{s}$ (assuming a normal right atrial pressure of $5 \mathrm{mmHg}$ ) equates to mild pulmonary hypertension. It should be noted that the pulmonary artery pressure falls in the presence of moderate to severe right ventricular impairment, thus underestimating the severity of pulmonary vascular disease. A Doppler estimate of pulmonary artery systolic pressure should be considered a screening test and a specialist cardiac opinion sought if pulmonary hypertension is suspected.

The risk of maternal death is high even in the presence of mild pulmonary hypertension. Furthermore, recent UK maternal mortality data suggest that pregnancy can be associated with progression of pulmonary hypertension. ${ }^{1}$

\section{Significant left heart obstruction}

Significant left heart obstruction as defined by echocardiography:

Mitral stenosis: mitral valve area $<1.0 \mathrm{~cm}^{2}$

Aortic stenosis: aortic valve area $<1.0 \mathrm{~cm}^{2}$ or (nonpregnant) mean gradient $>50 \mathrm{mmHg}$.

Lower aortic valve pressure differences may be falsely reassuring: if left ventricular systolic function is impaired, the left ventricle may not be capable of generating a high gradient across the aortic valve. In addition, if the patient is symptomatic, has a blood pressure which fails to rise normally in response to exercise, marked ST segment changes or impaired left ventricular function, then pregnancy can be very high risk, whatever the estimated Doppler gradient.

It should be remembered that the increased cardiac output of pregnancy increases the Doppler flow velocity and hence the estimated gradient across the aortic valve. Failure of the aortic valve gradient to rise during pregnancy may therefore indicate a failing left ventricle.

\section{Marfan syndrome}

Type A aortic dissection is the main maternal risk in Marfan syndrome; it carries a $22 \%$ mortality in pregnancy. ${ }^{10}$ The overall risk of maternal death is approximately $1 \%$. Women at particularly high risk include those with a poor family history, cardiac involvement and aortic root $>4 \mathrm{~cm}$ diameter or a rapidly dilating aorta. ${ }^{11,12}$

Class 2 and 3 Conditions (Table 3)

- Class 2 conditions: pregnancy presents a small increased risk of maternal mortality or morbidity.

Table 3 Conditions in which pregnancy is Class 2 or 3

\begin{tabular}{|c|c|c|}
\hline $\begin{array}{l}\text { Class } 2 \text { if otherwise } \\
\text { well and } \\
\text { uncomplicated }\end{array}$ & $\begin{array}{l}\text { Class 2-3 depending } \\
\text { on individual }\end{array}$ & Class $3^{a}$ \\
\hline $\begin{array}{l}\text { Unoperated atrial } \\
\text { septal defect }\end{array}$ & $\begin{array}{l}\text { Mild left ventricle } \\
\text { impairment }\end{array}$ & Mechanical valve \\
\hline $\begin{array}{l}\text { Repaired tetralogy } \\
\text { of Fallot }\end{array}$ & $\begin{array}{l}\text { Hypertrophic } \\
\text { cardiomyopathy }\end{array}$ & $\begin{array}{l}\text { Systemic right } \\
\text { ventricle }^{b}\end{array}$ \\
\hline \multirow[t]{3}{*}{ Arrhythmias } & $\begin{array}{l}\text { Native or tissue valvular } \\
\text { heart disease not } \\
\text { considered Class } 4\end{array}$ & $\begin{array}{l}\text { Post Fontan } \\
\text { operationc }^{c}\end{array}$ \\
\hline & $\begin{array}{l}\text { Marfan syndrome without } \\
\text { aortic dilation (with/without } \\
\text { a family history of aortic } \\
\text { dissection) }\end{array}$ & $\begin{array}{l}\text { Cyanotic heart } \\
\text { disease }\end{array}$ \\
\hline & Heart transplantation & $\begin{array}{l}\text { Other complex } \\
\text { congenital heart } \\
\text { disease }\end{array}$ \\
\hline
\end{tabular}

aClass 3 unless other risk factors, in which case pregnancy may carry a Class 4 risk.

bCongenital heart disease in which the right ventricle supports the systemic circulation.

cFontan operation for tricuspid atresia and other conditions where there is only one functional ventricle. The single ventricle is used to support the systemic circulation. This results in a low cardiac output, hypercoagulable circulation. 
Table 4 Conditions in which pregnancy is Class 1

Uncomplicated, small or mild

Pulmonary stenosis

Ventricular septal defect

Patent ductus arteriosus

Mitral valve prolapse with no more than trivial mitral regurgitation

Successfully repaired simple lesions

Ostium secundum atrial septal defect

Ventricular septal defect

Patent ductus arteriosus

Total anomalous pulmonary venous drainage

Isolated ventricular extrasystoles and atrial ectopic beats

- Class 3 conditions: pregnancy presents a significantly increased risk of maternal mortality or severe morbidity. Expert counselling required. If pregnancy is decided upon, intensive specialist cardiac and obstetric monitoring needed throughout pregnancy, childbirth and the puerperium.

Patients with the conditions listed in Table 3 fall into either Class 2 or Class 3 categories depending on individual circumstances; they require individual assessment in a specialist unit. All women with these conditions may go up a class or more if there are additional risk factors such as the need for anticoagulation, or a combination of conditions. For example, pregnancy in a woman with repaired tetralogy of Fallot with atrial arrhythmias and mild left ventricle impairment may be associated with Class 3 risk.

In addition, cyanosis with a pre-pregnancy resting arterial oxygen saturation $<85 \%$ is associated with only a $12 \%$ chance of livebirth, ${ }^{13}$ and this fetal risk should also be considered when assessing maternal risk.

\section{Class 1 Conditions (Table 4)}

- Pregnancy presents no detectable increased risk of maternal mortality or morbidity.

\section{Sterilisation}

Although sterilisation may appear to be the obvious choice for many women who should not get pregnant, it is rated WHO 2 at best because of the risks associated with the procedure itself, its late failure rate, its psychological impact on the patient, and the availability of secure and safe alternatives.

Late sterilisation failure rates are higher in young women. ${ }^{14,15}$ They may result in ectopic pregnancies, the management of which is a major problem in women with heart disease or pulmonary vascular disease, especially if the patient is taking anticoagulants.

For laparoscopic sterilisation under general anaesthetic, the combination of positive-pressure ventilation, abdominal insufflation with $\mathrm{CO}_{2}$ and intermittent head down tilt all decrease venous return, an effect which is poorly tolerated by those with pulmonary vascular disease or a Fontan circulation (see footnote to Table 3). Use of local anaesthetic is an attractive option in skilled hands, but not for those with pulmonary vascular disease, because of the risk of vagal reactions to which such patients are particularly vulnerable. Patients with right-to-left shunts are also at risk of paradoxical embolism both from air emboli from venous catheters and from the soluble $\mathrm{CO}_{2}$ used for insufflation.

The safest surgical technique is probably minilaparotomy or minimal laparoscopy (with $<200 \mathrm{ml} \mathrm{CO} 2$ and negligible increases in intra-abdominal pressure). This can be performed using the safest anaesthetic regime for patients with pulmonary vascular disease (i.e. low-dose neuraxial block with combined spinal and epidural block). High-risk patients should receive invasive monitoring in the perioperative period.
Sterilisation can be done at the time of Caesarean section, thus avoiding the risk of a separate procedure. However, the failure rate is higher than when performed as a separate procedure. 15

The place of the new hysteroscopic sterilisation technique known as Essure ${ }^{\circledR}$ is unclear. ${ }^{16}$ Special intratubal stents are inserted, usually with no more than oral analgesia, and the risk of vagal reactions may be reduced using the anaesthetic techniques described above. Early efficacy testing at 3 months reports no failures to date.

Vasectomy is rarely appropriate. The male partner of a woman with severe cardiovascular or pulmonary vascular disease is likely to outlive her and may wish to father children with a new partner.

The role of sterilisation has been reduced by some of the reversible contraceptive techniques such as the intrauterine system (IUS) (Mirena ${ }^{\circledR}$ ) and the subdermal implant $\left(\right.$ Implanon $\left.{ }^{\circledR}\right)$, both of which are as effective as sterilisation. In addition, some women will not be able to accept the finality of never being able to have children and therefore alternatives to sterilisation are welcome.

\section{Contraceptive methods}

The principle of 'Summation of Risk' applies to individual contraceptive methods, namely that a contraceptive method should be avoided in general if its adverse effects summate with a known risk of the (heart) disease. ${ }^{2}$

\section{Combined hormonal contraceptives}

Combined oral contraceptives. The combined oral contraceptive pill (COC) is a safe, effective and popular method of contraception. The estrogen component is associated with increased risk of arterial and venous thromboembolism. It is this association that limits the use of the COC in some women with cardiovascular disease (Table 5).

The risk of ischaemic stroke associated with the COC is increased by additional vascular risk factors including smoking, hypertension, diabetes, obesity and migraine, especially migraine with aura.

Women whose cardiac status is prothrombotic may be at particular risk, and careful consideration should be given to the use of the $\mathrm{COC}$ as opposed to alternative progestogen-only contraceptive methods. Anticoagulation does not protect entirely against the further thrombotic risk of the combined pill. In addition, both estrogens and progestogens may interfere with warfarin metabolism, so the international normalised ratio (INR) should be monitored more frequently when initiating the COC. Hence, even if a patient is anticoagulated with warfarin the COC would be classified at minimum as WHO 3 , usually reverting to WHO 4 if anticoagulation ceases.

Women with right-to-left shunts due to cyanotic heart disease or pulmonary arteriovenous malformations are at risk of paradoxical embolism and stroke if they develop venous thrombosis whilst on the COC; it is contraindicated (WHO 4) in these women. Although an uncomplicated, unoperated atrial septal defect results in left-to-right shunting, it is possible to reverse the shunt with simple physiological manoeuvres (e.g. Valsalva) and so women with atrial septal defect should also consider other forms of contraception, especially if they have additional risk factors for thromboembolism (WHO 3).

Paradoxically, because of its benign nature, advice for women with known patent foramen ovale (PFO) is more complex. Although PFO is associated with embolic stroke, ${ }^{17}$ it is a normal variant that occurs in $10-20 \%$ of the population, remaining asymptomatic and undiagnosed in 


\section{REVIEW}

Table 5 World Health Organization (WHO) risk classification for the use of combined hormonal contraceptives (i.e. COCs, Evra ${ }^{\circledR}$ and NuvaRing $\left.{ }^{\circledR}\right)$

\begin{tabular}{|c|c|c|c|}
\hline WHO 1 & WHO 2 & WHO 3 & WHO 4 \\
\hline $\begin{array}{l}\text { Condition with no restriction for the } \\
\text { use of the contraceptive method }\end{array}$ & $\begin{array}{l}\text { Condition where the advantages of } \\
\text { the method generally outweigh the } \\
\text { risks }\end{array}$ & $\begin{array}{l}\text { Condition where the risks of the } \\
\text { method usually outweigh the } \\
\text { advantages: consider carefully all } \\
\text { alternatives first }{ }^{\mathrm{a}}\end{array}$ & $\begin{array}{l}\text { Condition where the method } \\
\text { represents an unacceptable health risk }\end{array}$ \\
\hline Always usable & Broadly usable & Caution in use & Do not use \\
\hline $\begin{array}{l}\text { Physiological murmurs in absence of } \\
\text { heart disease }\end{array}$ & $\begin{array}{l}\text { Most arrhythmias other than atrial } \\
\text { fibrillation or flutter }\end{array}$ & $\begin{array}{l}\text { Atrial fibrillation or flutter on } \\
\text { warfarin }^{\mathrm{b}}\end{array}$ & $\begin{array}{l}\text { Atrial fibrillation or flutter, if not } \\
\text { anticoagulated }\end{array}$ \\
\hline $\begin{array}{l}\text { Mitral valve prolapse with or trivial } \\
\text { mitral regurgitation }\end{array}$ & $\begin{array}{l}\text { Uncomplicated mild native mitral and } \\
\text { aortic valve disease }\end{array}$ & $\begin{array}{l}\text { Bi-leaflet mechanical valve in mitral } \\
\text { or aortic position taking warfarin }\end{array}$ & $\begin{array}{l}\text { Bjork Shiley or Starr Edwards valves } \\
\text { even taking warfarin }\end{array}$ \\
\hline $\begin{array}{l}\text { Bicuspid aortic valve with normal } \\
\text { function }\end{array}$ & $\begin{array}{l}\text { Tissue prosthetic valve lacking any of } \\
\text { the features noted in WHO } 3 \text { and } 4 \\
\text { columns }\end{array}$ & $\begin{array}{l}\text { Atrial septal defect with left-to-right } \\
\text { shunt that may reverse with } \\
\text { physiological stress (e.g. Valsalva } \\
\text { manoeuvre) }\end{array}$ & $\begin{array}{l}\text { Pulmonary hypertension or pulmonary } \\
\text { vascular disease (e.g. Eisenmenger's } \\
\text { syndrome) }\end{array}$ \\
\hline Mild pulmonary stenosis & $\begin{array}{l}\text { Surgically corrected congenital heart } \\
\text { disease lacking any of the features } \\
\text { noted in WHO } 3 \text { or } 4 \text { columns }\end{array}$ & $\begin{array}{l}\text { Repaired coarctation with aneurysm } \\
\text { and/or hypertension }\end{array}$ & Dilated left atrium $>4 \mathrm{~cm}$ \\
\hline $\begin{array}{l}\text { Repaired coarctation with no } \\
\text { hypertension or aneurysm }\end{array}$ & $\begin{array}{l}\text { Small left-to-right shunt not } \\
\text { reversible with physiological } \\
\text { manoeuvres (e.g. small VSD, small } \\
\text { patent ductus arteriosus) }\end{array}$ & $\begin{array}{l}\text { Marfan syndrome with aortic } \\
\text { dilatation unoperated }\end{array}$ & Fontan heartc even taking warfarin \\
\hline $\begin{array}{l}\text { Other simple lesions successfully } \\
\text { repaired in childhood and with no } \\
\text { sequelae e.g. }\end{array}$ & Uncomplicated Marfan syndrome & $\begin{array}{l}\text { Past thromboembolic event on } \\
\text { warfarinb }\end{array}$ & $\begin{array}{l}\text { Cyanotic heart disease even taking } \\
\text { warfarin }\end{array}$ \\
\hline $\begin{array}{l}\text { Ostium secundum atrial septal } \\
\text { defect }\end{array}$ & $\begin{array}{l}\text { Hypertrophic cardiomyopathy } \\
\text { (HOCM) lacking any of the features } \\
\text { noted in the WHO } 3 \text { and } 4 \text { columns }\end{array}$ & & $\begin{array}{l}\text { Pulmonary arteriovenous } \\
\text { malformation }\end{array}$ \\
\hline Ventricular septal defect & $\begin{array}{l}\text { Past cardiomyopathy, fully recovered, } \\
\text { including peripartum cardiomyopathy }\end{array}$ & & $\begin{array}{l}\text { Past thromboembolic event (venous or } \\
\text { arterial) not taking warfarin }\end{array}$ \\
\hline Patent ductus arteriosus & & & $\begin{array}{l}\text { Poor left ventricle function of any } \\
\text { cause (e.g. dilated cardiomyopathy) } \\
\text { (ejection fraction <30\%) }\end{array}$ \\
\hline $\begin{array}{l}\text { Total anomalous pulmonary venous } \\
\text { drainage }\end{array}$ & & & $\begin{array}{l}\text { Coronary artery disease } \\
\text { Coronary arteritis (e.g. previous } \\
\text { Kawasaki's disease with coronary } \\
\text { involvement) }\end{array}$ \\
\hline
\end{tabular}

aWHO 3: alternatives are usually preferable. Exceptions if: (i) the patient accepts risks and rejects alternatives or (ii) the risk of pregnancy is very high and the only acceptable alternative methods are less effective.

bWarfarin: care with monitoring the international normalised ratio (INR), which may alter with both estrogen and progestogen hormone therapy.

cFontan operation for tricuspid atresia and other conditions where there is only one functional ventricle. The single ventricle is used to support the systemic circulation. This results in a low cardiac output, hypercoagulable circulation.

NB. In the presence of any feature listed in the third or fourth columns of the table, the more exclusive category should be applied. For example, mitral valve disease with dilated left atrium moves to WHO 4. Furthermore, the presence of two or more features in the WHO 2 or 3 columns or the addition of an independent risk factor such as smoking or hypertension generally contraindicates combined oral contraceptive use (i.e. WHO 4).

most individuals. ${ }^{18}$ Women whose PFO was discovered because of a clinical event such as embolic stroke or neurological decompression sickness after diving should be advised against using the COC (WHO 4). For women in whom PFO is an incidental finding, this working group classifies its use as a 'permissive' WHO 2, since there is a theoretical, but very small, risk of paradoxical embolism. The working group certainly does not advocate screening for PFO in asymptomatic women seeking to use the COC.

New combined non-oral contraceptives. EVRA ${ }^{\circledR}$, a combined contraceptive skin patch, is available, and NuvaRing ${ }^{\circledR}$, a combined contraceptive vaginal ring, although not yet available in the UK, is licensed in several other countries. Since these methods contain ethinylestradiol and a progestogen (norelgestromin and etonogestrel, respectively), similar eligibility criteria - and side effects - apply as for the COC.

\section{Progestogen-only methods}

Contraceptive doses of progestogens used alone are not associated with an increased risk of arterial or venous thrombosis. ${ }^{19-21}$ Therefore all progestogen-only methods are usable when there is an arterial or venous thrombotic risk and, broadly speaking, are safe for all forms of heart disease (Table 6). However, progestogens may sometimes interact with warfarin to affect the INR, so additional anticoagulation monitoring should be advised early in their use and when they are discontinued.

\section{Progestogen-only pills}

Progestogen-only pills (POPs), although safe in cardiac disease, are is generally not recommended for those with major heart disease (pregnancy WHO Class 3-4) where maximum efficacy is needed.

The new POP, Cerazette ${ }^{\circledR}$ (desogestrel $75 \mu \mathrm{g}$ ), may be extremely useful for women who are unable to take the $\mathrm{COC}$ and require reliable contraception. ${ }^{2}$ In contrast to 
Table 6 Safety of progestogen-only contraceptive methods in women with heart disease

\begin{tabular}{|c|c|c|}
\hline $\begin{array}{l}\text { Progestogen-only } \\
\text { contraceptive methoda }\end{array}$ & Cardiac condition & WHO Class \\
\hline Standard $\mathrm{POP}^{\mathrm{b}}$ & All cardiac patients & 1 \\
\hline Cerazette ${ }^{\circledR}$ POPc & All cardiac patients & 1 \\
\hline \multirow[t]{2}{*}{ Depo-Provera ${ }^{\circledR}$} & $\begin{array}{l}\text { All cardiac patients not on } \\
\text { warfarin }\end{array}$ & 1 \\
\hline & $\begin{array}{l}\text { All cardiac patients taking } \\
\text { warfarin }^{\mathrm{d}}\end{array}$ & 3 \\
\hline Implanon ${ }^{\circledR c}$ & All cardiac patients & 1 \\
\hline \multirow[t]{5}{*}{ Mirena ${ }^{\circledR}$ IUS } & $\begin{array}{l}\text { Cardiac patients generally, } \\
\text { even if taking warfarin }\end{array}$ & 1 \\
\hline & $\begin{array}{l}\text { Structural heart disease }{ }^{\mathrm{e}} \text {, } \\
\text { except as below }\end{array}$ & 2 \\
\hline & Prosthetic heart valves ${ }^{a, e}$ & 3 \\
\hline & Previous endocarditis & 3 \\
\hline & $\begin{array}{l}\text { Pulmonary hypertension, } \\
\text { Fontan circulation }{ }^{\mathrm{f}} \text {, or other } \\
\text { condition in which vagal } \\
\text { reaction at insertion would be } \\
\text { poorly toleratedg }\end{array}$ & $4(3)$ \\
\hline $\begin{array}{l}\text { Emergency contraception } \\
\left.\text { (Levonelle }{ }^{\circledR}\right)\end{array}$ & All cardiac disease ${ }^{c}$ & 1 \\
\hline
\end{tabular}

aWarfarin: care with monitoring the international normalised ratio (INR), which may alter after initiation of any progestogen hormone therapy. The effect of the exceptionally low levonorgestrel blood levels with the Mirena IUS is unknown, likely minimal.

bAlthough safe, the standard progestogen-only pill is less effective than all the other progestogen-only methods. It should not normally be advised where pregnancy poses a high or unacceptable risk (Class 3 and 4 conditions).

cEfficacy reduced by bosentan (see text).

dRisk of large haematoma at site of injection.

eIf used, appropriate parenteral antibiotic cover (see British National Formulary) is advised to prevent endocarditis following insertion.

fFontan operation for tricuspid atresia and other conditions where there is only one functional ventricle. The single ventricle is used to support the systemic circulation. This results in a low cardiac output, hypercoagulable circulation

gSee text, may be used if no other method suitable and risk of pregnancy outweighs risk of insertion.

IUS, intrauterine system; POP, progestogen-only pill.

older POPs, the primary action of Cerazette is anovulatory. Hence Cerazette has similar efficacy to the COC and a 12hour 'window' for missed pills.

Because Cerazette is the prodrug for the same progestogen as released by the Implanon implant (see below) it can be useful for trial before the latter, to assess non-bleeding hormonal side effects. Users must be warned concerning the likelihood of irregular bleeding.

Standard POPs are contraindicated (WHO 4) for women receiving bosentan for pulmonary hypertension. Bosentan is an endothelin antagonist and is also an enzyme inducer and may reduce the efficacy of progestogen-only contraceptives. It is extremely important to avoid pregnancy in this group of patients; therefore, on efficacy grounds, Cerazette (at increased dose) would be the only appropriate POP (WHO 3) for use in these women. The Mirena IUS and Depo-Provera ${ }^{\circledR}$ are not affected by bosentan, but the working group considered that insertion of Mirena is particularly high risk in pulmonary hypertension and therefore contraindicated (see below).

\section{Depo-Provera}

This is a highly effective injectable contraceptive method with no cardiac contraindications. To maintain efficacy, compliance with 12-weekly injections is imperative, fertility frequently returning to normal if injections are delayed. Furthermore, the deep intramuscular injections may cause significant haematomas in those who are anticoagulated with warfarin (WHO 3). Many women become amenorrhoeic with continued use, which is an advantage, especially for women receiving warfarin or with cyanotic heart disease, many of whom suffer from menorrhagia.

\section{Implanon}

The progestogen (etonogestrel) implant known as Implanon has no cardiac contraindications, is as effective as sterilisation and produces steadier blood levels (and generally fewer side effects) than Depo-Provera. There is much less risk of haematoma formation, as the implant is subdermal and only needs replacing every 3 years. Around $20 \%$ of women using Implanon become amenorrhoeic, which is again an advantage for those with menorrhagia.

The efficacy of Implanon is also affected by bosentan, so a supplementary method of contraception (most appropriately Cerazette, which contains the same progestogen) should be used in order to provide secure contraception for women with pulmonary hypertension.

\section{Mirena IUS}

This hormone-releasing IUS does not have the risks of increased vaginal bleeding and pain that are associated with the older copper intrauterine devices (IUDs); indeed most women become oligo-amenorrhoeic, a major advantage to many women with cardiac disease. The method has a similar efficacy to sterilisation.

As with copper IUDs, there is a risk of infection at the time of insertion, which makes screening in advance for sexually transmitted infection (STI) necessary. The insertion should be covered with antibiotics in those patients with heart disease who are at risk of bacterial endocarditis (as directed by the British National Formulary).

The IUS may appropriately be inserted in those who have not had children (WHO 2). For the majority of women with heart disease (not pulmonary vascular disease or the Fontan circulation, see below) the Mirena system may be classed: WHO 1 once successfully inserted; WHO 2 if there is an insertion risk of infective endocarditis (given appropriate antibiotic cover at insertion); WHO 3 in a patient with a prosthetic valve; and WHO 4 if the endocarditis risk is unusually high (e.g. a patient with previous endocarditis).

It should be noted that up to $5 \%$ of women experience a vasovagal response at the time the cervix is instrumented for insertion of the device. Such a response carries a significant risk of cardiovascular collapse in those with pulmonary vascular disease or a Fontan circulation (see footnote to Table 3). In the case of pulmonary vascular disease, a vagal reaction may be fatal. The use of atropine does not guarantee safety from vagal reactions. Paracervical block may help to prevent vagal reactions although combined spinal and epidural block may be a better option. Overall, this working group believes that the progestogen implant (Implanon) is a better option to both the IUS and a copper IUD for women in whom vagal reactions carry a risk of cardiovascular collapse. However, if Implanon results in unacceptable bleeding, then the risk of pregnancy in a pulmonary hypertensive woman may outweigh the risk of Mirena insertion by a skilled operator.

\section{Standard IUD}

Provided a banded copper IUD is used, ${ }^{2}$ these have the useful advantage of needing less frequent replacement (10 years in the case of the current 'gold standard', T-Safe ${ }^{\circledR} \mathrm{CU}$ 380 A) than the Mirena IUS, and may suit women with heart disease if they initially have light and pain-free 
Table 7 World Health Organization (WHO) Class for contraceptive methods in specific clinical conditions ${ }^{\mathrm{a}}$

\begin{tabular}{|c|c|c|c|c|c|c|c|c|}
\hline Clinical condition & $\begin{array}{l}\text { Combined } \\
\text { hormonal } \\
\text { methods } \\
\text { (estrogen } \\
\text { containing) }\end{array}$ & $\begin{array}{l}\text { POP } \\
\text { ('minipill') }\end{array}$ & Cerazette $^{\circledR}$ & Implanon $^{\circledR}$ & $\begin{array}{l}\text { Depo- } \\
\text { Provera }^{\circledR}\end{array}$ & $\begin{array}{l}\text { Mirena }{ }^{\circledR} \\
\text { IUS }\end{array}$ & $\begin{array}{l}\text { Standard } \\
\text { IUD }\end{array}$ & $\begin{array}{l}\text { Emergency } \\
\text { hormonal } \\
\text { contraception }\end{array}$ \\
\hline Physiological murmur & 1 & 1 & 1 & 1 & 1 & 1 & 1 & 1 \\
\hline $\begin{array}{l}\text { Paroxysmal AF (even on warfarin }{ }^{\mathrm{b}} \text { ) } \\
\text { with structurally normal heart }\end{array}$ & 3 & 1 & 1 & 1 & $\begin{array}{l}1(3 \\
\text { on warfarin) }\end{array}$ & 1 & 1 & 1 \\
\hline Repaired Fallot without complications & 1 & 1 & 1 & 1 & 1 & 1 & 2 & 1 \\
\hline Unoperated atrial septal defect & 3 & 1 & 1 & 1 & 1 & 1 & 1 & 1 \\
\hline Dilated cardiomyopathy & 4 & $(1)^{\mathrm{c}}$ & 1 & 1 & $\begin{array}{l}1(3 \\
\left.\text { on warfarin }{ }^{b}\right)\end{array}$ & 1 & 1 & 1 \\
\hline Moderate aortic stenosis & 2 & 1 & 1 & 1 & 1 & 2 & 3 & 1 \\
\hline Bjork Shiley mitral valve replacement ${ }^{b}$ & 4 & 1 & 1 & 1 & 3 & 3 & 4 & 1 \\
\hline Bileaflet mitral valve replacement ${ }^{b}$ & 3 & 1 & 1 & 1 & 3 & 3 & 4 & 1 \\
\hline $\begin{array}{l}\text { Cyanotic heart disease without } \\
\text { pulmonary hypertension }\end{array}$ & 4 & $(1)^{\mathrm{c}}$ & 1 & 1 & $\begin{array}{l}2(3 \\
\left.\text { on } \text { warfarin }^{b}\right)\end{array}$ & 2 & 3 & 1 \\
\hline $\begin{array}{l}\text { Eisenmenger syndrome and pulmonary } \\
\text { hypertension of any cause }\end{array}$ & 4 & $(1)^{\mathrm{c}}$ & 1 & 1 & 1 & $4\left(3^{d}\right)$ & 4 & 1 \\
\hline Fontan circulation even on warfarin ${ }^{b}$ & 4 & $(1)^{\mathrm{c}}$ & 1 & 1 & 3 & $4\left(3^{\mathrm{d}}\right)$ & 4 & 1 \\
\hline
\end{tabular}

aSee sections of text on specific contraceptive methods for more information.

bWarfarin: care with monitoring the international normalised ratio (INR), which may alter with both estrogen and progestogen hormone therapy. With DepoProvera there is a specific risk of local haematoma (see text).

cAlthough safe, the limited efficacy of the progestogen-only pill limits its use in women in whom pregnancy carries a particular risk (Class 3 or 4 , as in Tables 2 and 3 ).

dMay be used if no other method suitable and risk of pregnancy outweighs risk of insertion

IUD, intrauterine device; IUS, intrauterine system; POP, progestogen-only pill.

periods. Though $\mathrm{WHO}^{5}$ itself classifies copper IUDs as WHO 2 in patients with 'complicated' valvular heart disease, this working group has graded copper IUDs WHO 3 because the risk of endocarditis is theoretically likely to be greater than with the Mirena IUS (since progestogenic mucous effects may reduce uterine entry of pathogens).

In those with pulmonary vascular disease, similar constraints apply to insertion as discussed above for the IUS.

The risk of menorraghia in those who are anticoagulated makes copper IUDs WHO 3 (i.e. even after successful insertion)

\section{Emergency contraception}

This is safe for all women with heart disease (WHO 1) as it contains no estrogen. The licensed formulation is levonorgestrel $1500 \mu \mathrm{g}$ (Levonelle ${ }^{\circledR}$ ) given as a single dose. If initiated within 72 hours of sexual exposure this has overall a $1 \%$ failure rate. ${ }^{2}$ About $15 \%$ of women will experience nausea and $1.5 \%$ vomit.

The efficacy of emergency contraception may be reduced in patients on bosentan (see above). If required, the dose should be increased by $50-100 \%$.

Emergency contraception is not recommended as a regular long-term contraceptive technique due to its high annual failure rate, plus its lack of protection against STIs. Indeed, if there is not mutually assured monogamy, all the above methods need supplementation by male (or female) condom use.

\section{Contraceptive advice for particular clinical situations}

When discussing contraceptive options with a woman with heart disease, the first decision is usually whether the COC is safe, as shown in Table 5. Following this, a decision has to be made as to which of the progestogen-only methods may be recommended. Whilst there are no cardiac contraindications to progestogen itself, consideration must be given to the actual method, namely whether there is a risk of endocarditis or haemodynamic collapse at insertion of an IUS, or a risk of haematoma with Depo-Provera injection. In addition to safety, the efficacy of the contraceptive method should be considered; for example, although safe, the low efficacy of the POP 'minipill' means it is not a desirable choice for women in whom pregnancy carries a very high risk.

Table 7 illustrates the relative advisability of different contraceptive methods for particular difficult or common clinical situations.

\section{Conclusions}

This review aims to offer practical guidance for clinicians including cardiologists, obstetricians, general practitioners and family planning experts in order that the increasing numbers of women with heart disease can gain access both to safe and reliable contraception and to advice about their risks in pregnancy.

Inevitably the suggested gradings for pregnancy and contraception are arbitrary. They are based on the evidence available when this review was written, and on expert clinical opinion with assessment of the natural history and particular risks associated with each condition. There could be much more confidence about these gradings if large prospective studies of outcome in various forms of heart disease using different contraceptive methods were available. There is a real need for such studies.

\section{Statements on funding and competing interests}

Funding. None identified.

Competing interests. John Guillebaud and Anne MacGregor have received lecture fees, research grants, ad hoc consultancy fees and payments for expenses from the manufacturers of contraceptive products. There are no other conflicts of interest.

\section{References}

1 Lewis G (ed.). Why Mothers Die 2000-2002. The Sixth Report of Confidential Enquiries into Maternal Deaths in the United Kingdom. London, UK: RCOG Press, 2004.

2 Guillebaud J. Contraception Today (5th edn). London, UK: Taylor \& Francis, 2003

3 Leonard H, O'Sullivan JJ, Hunter S. Family planning requirements in the adult congenital heart disease clinic. Heart 1996; 76: 60-62.

4 Guillebaud J. Medical-eligibility criteria for contraceptive use. Lancet 2001; 357: 1378-1379. 
5 World Health Organization (WHO). Medical Eligibility Criteria for Contraceptive Use (3rd edn). Geneva, Switzerland: WHO, 2004.

6 Siu SC, Sermer M, Colman JM, Alvarez AN, Mercier LA, Morton $\mathrm{BC}$, et al; Cardiac Disease in Pregnancy (CARPREG) Investigators. Prospective multicenter study of pregnancy outcomes in women with heart disease. Circulation 2001; 104: 515-521

7 The Task Force on Diagnosis and Treatment of Pulmonary Arterial Hypertension of the European Society of Cardiology. Guidelines on diagnosis and treatment of pulmonary arterial hypertension. Eur Heart J 2004; 25: 2243-2278.

8 McQuillan BM, Picard MH, Leavitt M, Weyman AE. Clinical correlates and reference intervals for pulmonary artery systolic pressure among echocardiographically normal subjects. Circulation 2001; 104: 2797-2802

9 Weiss BM, Zemp L, Seifert B, Hess OM. Outcome of pulmonary vascular disease in pregnancy: a systematic overview from 1978 though 1996. J Am Coll Cardiol 1998; 31: 1650-1657.

10 Weiss BM, von Segesser LK, Alon E, Seifert B, Turina MI. Outcome of cardiovascular surgery and pregnancy: a systematic review of the period 1984-1996. Am J Obstet Gynecol 1998; 179(6 Pt 1): 1643-1653.

11 Lind J, Wallenburg HC. The Marfan syndrome and pregnancy: a retrospective study in a Dutch population. Eur J Obstet Gynecol Reprod Biol 2001; 98: 28-35.

12 Elkyam U, Ostrzega E, Shotan A, Mehra A. Cardiovascular problems in pregnant women with the Marfan syndrome. Ann Intern Med 1995; 123: $117-122$.

13 Presbitero P, Somerville J, Stone S, Aruta E, Spiegelhalter D, Rabajoli F. Pregnancy in cyanotic congenital heart disease. Circulation 1994; 89: $2673-2676$
14 Peterson HB, Xia Z, Hughes JM, Wilcox LS, Tylor LR, Trussell J. The risk of pregnancy after tubal sterilisation: findings from the US Collaborative Review of Sterilisation [CREST Study]. Am J Obstet Gynecol 1996; 174: 1161-1170.

15 Royal College of Obstetricians and Gynaecologists (RCOG). Male and Female Sterilisation (National Evidence-Based Clinical Guideline No. 4). London, UK: RCOG Press, 2003.

16 Kerin JF, Cooper JM, Price T, Herendael BJ, Cayuela-Font E, Cher D, et al. Hysteroscopic sterilization using a micro-insert device: results of a multicentre Phase II study. Hum Reprod 2003; 18: 1223-1230.

17 Lechat P, Mas JL, Lascault G, Loron P, Theard M, Klimczac M, et al. Prevalence of patent foramen ovale in patients with stroke. $N$ Engl J Med 1988; 318: 1148-1152.

18 Kerut EK, Norfleet WT, Plotnick GD, Giles TD. Patent foramen ovale: a review of associated conditions and the impact of physiological size. J Am Coll Cardiol 2001; 38: 613-623.

19 Vasilakis C, Jick H, del Mar Melero-Montes M. Risk of idiopathic venous thromboembolism in users of progestogens alone. Lancet 1999; 354: 1610-1611.

20 Collaborative Study of Cardiovascular Disease and Steroid Hormone Contraception, World Health Organization. Cardiovascular disease and use of oral and injectable progestogen-only contraceptives and combined injectable contraceptives. Contraception 1998; 57: $315-324$.

21 Heinemann LAJ, Assman A, DoMinh T, Garbe E and the Transnational Research Group on Oral Contraceptives and the Health of Young Women. Oral progestogen-only contraceptives and cardiovascular risk: results from the Transnational Study on Oral Contraceptives and the Health of Young Women. Eur J Contracept Reprod Health Care 1999; 4: 67-73.

\section{Visit the Faculty Website at: www.ffprhc.org.uk}

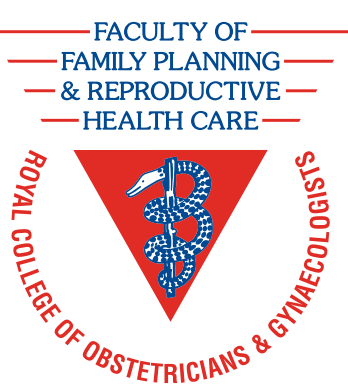

Article 3.9: Persons not medically qualified but who have made an important contribution to and are working in the sphere of the Faculty and medical practitioners who are permanently retired from clinical practice, due to age or ill health, may on application to the Council be accepted for Associate Membership.

This subscription entitles Associate Members to copies of the Journal of Family Planning and Reproductive Health Care and access to the members' enquiry service.

The Journal of Family Planning and Reproductive Health Care is published quarterly, on behalf of the Faculty of Family Planning and Reproductive Health Care, by PMH Publications.

Membership now includes FREE access to the electronic journal, managed by Ingenta.

Associate Membership Application Forms are available on the website: www.ffprhc.org.uk or by telephoning: +44 (0)20 7724 5647/5669/5524

FACULTY OF FAMILY PLANNING AND REPRODUCTIVE HEALTH CARE of the Royal College of Obstetricians and Gynaecologists 27 Sussex Place, Regent's Park, London NW1 4RG, UK 